\title{
Contingency of the Destruction of Metals in Petroleum Oils
}

\author{
Suresh Aluvihara $^{1 *}$, Jagath K. Premachandra ${ }^{2}$ \\ ${ }^{1}$ Department of Chemical and Process Engineering, University of Peradeniya, Peradeniya 20400, Sri Lanka \\ ${ }^{2}$ Department of Chemical and Process Engineering, University of Moratuwa, Katubedda 10400, Sri Lanka
}

Corresponding Author Email: sureshaluvihare@gmail.com

https://doi.org/10.18280/eesrj.060203

Received: 28 February 2019

Accepted: 22 May 2019

\section{Keywords:}

crude oils, corrosive properties, ferrous metals, destruction, weight loss, corrosion

\begin{abstract}
Petroleum oils are multi composite earth resources including various corrosive compounds that able to cause the metallic corrosion. The investigations of the impacts of such corrosive compounds of petroleum oils on the corrosion of seven types of ferrous metals were the objectives. According to the methodology the chemical compositions of metals and the basic corrosive compounds presences in both petroleum oils were measured. The set of metal coupons with similar dimensions was prepared by the seven different types of metals and such metal coupons were immersed in both crude oils and after certain time periods the corrosion rates of such metal coupons were determined by the weight loss method with the microscopic analysis of the metal surfaces. The decayed ferrous and copper concentrations from metals and the variations of the initial hardness of metals were measured. As the results there were observed the relatively lower corrosion rates from stainless steels especially with the $\sim 12 \%$ of chromium with sufficient amount of nickel, higher corrosive impact from salts, formations of the $\mathrm{FeS}, \mathrm{Fe}_{2} \mathrm{O}_{3}$, corrosion cracks and pits, higher decay of copper and ferrous from some of metals and the slight reductions of the initial hardness of metals due to the corrosion.
\end{abstract}

\section{INTRODUCTION}

Petroelum oils are industrial usable energy sources that found as a dominant earth resource. The refining process of crude oils is linked with the wide range of applications of ferrous metals. According to the chemical compositions of such petroleum oils it is possible to find some corrosive compounds from that because of the abundancy of such corrosive compound in the interior part of the earth where the occurrence of such petroleum is happening [1-6].

According to the recent studies of chemical engineering that mainly found the impact of salts, organic acids and various forms of sulfur compounds on the corrosion of ferrous metals regarding the metal using industries foremost of the industry of crude oil refining. In the science behind the corrosion the incident of the corrosion is defined as the formations of the metal oxides, sulfides or the hydroxides on the metallic surfaces as a result of either chemical or electrochemical process due to the exposing of the metal against either strong oxidizing agent or any corrosive environment which is consisting both water and oxygen [2-15]. The behavior of the corrosion compound may be varied with the corrosive environments and conditions.

In the existing research basically there were expected to analyze the impact of salts, organic acids, elemental sulfur and Mercaptans on the corrosion of seven different types of ferrous metals which are applicable in the industry of petroleum oil refining regarding various units. The analysis was basically done as qualitatively and quantitatively.

\section{MATERIALS AND METHODOLOGY}

In the selections of the petroleum oils it was selected two different types of petroleum oils which are having slightly different chemical compositions including the corrosive compounds. Those crude oils are namely as Murban and Das Blend. According to the chemical compositions of such crude oils Das Blend crude oil may have some higher sulfur content which is an important factor for the corrosion [2, 9]. The predominant corrosive properties of both crude oils were measured by the standard instruments and methodologies as explained in the Table 1.

Table 1. Testing procedures of corrosive properties of crude oils

\begin{tabular}{c|c|c}
\hline Property & Method & Readings \\
\hline Sulfur content & $\begin{array}{c}\text { Directly used the crude } \\
\text { oil samples to the XRF } \\
\text { analyzer. }\end{array}$ & Direct reading \\
Acidity & $\begin{array}{c}\text { Each sample was } \\
\text { dissolved in a mixture } \\
\text { of toluene and } \\
\text { isopropyl and titrated } \\
\text { with potassium } \\
\text { hydroxide. }\end{array}$ & End point \\
Mercaptans & $\begin{array}{c}\text { Each sample was } \\
\text { dissolved in sodium } \\
\text { acetate and titrated } \\
\text { with silver nitrate. }\end{array}$ & End point \\
\hline Salt content & $\begin{array}{c}\text { Each sample was } \\
\text { dissolved in organic } \\
\text { solvent and exposed to } \\
\text { the cell of analyzer. }\end{array}$ & Direct reading \\
\hline
\end{tabular}


By considering the applicability of metals in the crude oil refining there were selected seven different types of ferrous metals for the existing research. Those metals and their typical applications have been given in the below.

$\checkmark$ Carbon Steel (High) - Transportation tubes, storage tanks $\checkmark$ Carbon Steel (Medium)- Storage tanks, heat exchangers

$\checkmark$ Carbon Steel (Mild Steel)- Storage tanks, heat exchangers

$\checkmark$ 410-MN: 1.8 420-MN: 2.8 (Stainless Steel)- Heat exchangers

$\checkmark$ 410-MN: 1.7 420-MN: 1.7 (Stainless Steel)- Crude distillation columns

$\checkmark$ 321-MN:1.4 304-MN:1.9 (Stainless Steel)- Crude distillation columns

$\checkmark$ Monel 400-Pre heaters, heat exchangers

A batch of similar sized metal coupons were prepared from seven different selected ferrous metals as six metal coupons from each metal type that altogether forty two metal coupons from all metal types. The prepared metal coupons have been shown in the Figure 1.

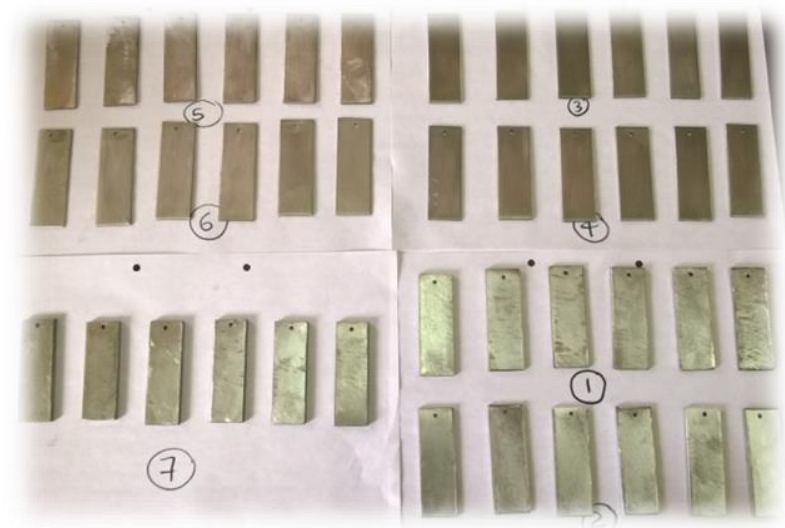

Figure 1. Prepared metal coupons

The dimensions and the initial weights of such metal were measured by in order of micrometers and analytical balance after proper cleaning of the metal surface until appearing the pure metal surface.

Fourteen crude oil containers were arranged as seven from Murban and Serven from Das Blend and the three homogeneous metal coupons were immersed in such crude oil containers as shown below.

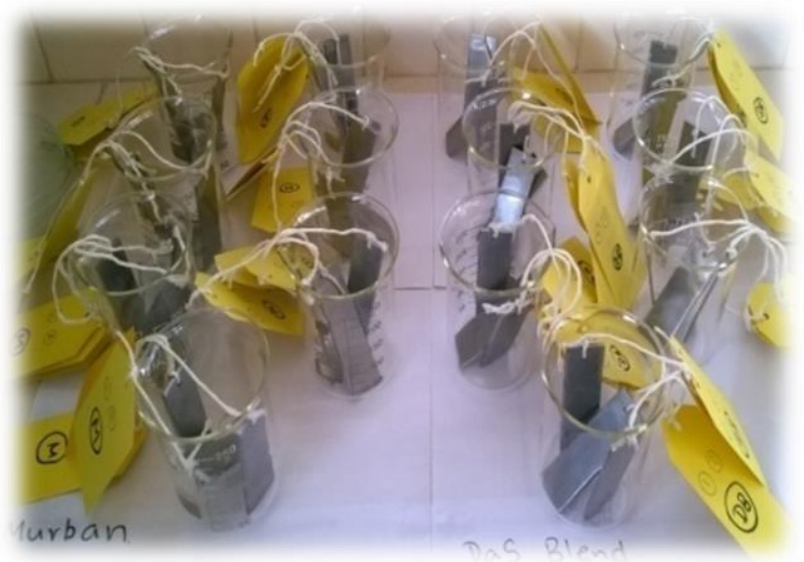

Figure 2. Batches of metal coupons

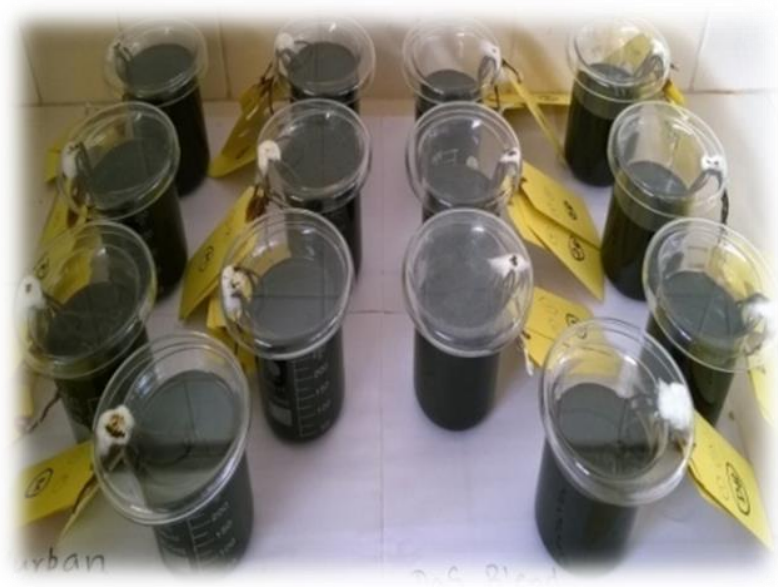

Figure 3. Apparatus setup

After 15 days from the immersion one metal coupon from each crude oil container altogether as fourteen metal coupons from all crude oil containers. The corroded surfaces of such metal coupons were observed under the $400 \mathrm{X}$ lens of an optical microscope and the corroded metal coupons were cleaned by the sand papers and isooctane until free of corroded particles and ultimately the final weight of the metal coupons were measured by the analytical balance to the determined the corrosion rates of such metal coupons by the weight loss method that discussed in the section of theories and methodologies $[9,10]$.

The mathematical formula and the terms of that formaula have been given in the below. This is the equation that to determine the corrosion rates of metal coupons $[9,10]$.

$$
\mathrm{CR}=\mathrm{W} * \mathrm{k} /(\mathrm{D} * \mathrm{~A} * \mathrm{t})
$$

where;

$\mathrm{W}=$ weight loss due to the corrosion in grams

$\mathrm{k}=$ constant $(22,300)$

$\mathrm{D}=$ metal density in $\mathrm{g} / \mathrm{cm}^{3}$

$\mathrm{A}=$ area of metal piece $\left(\right.$ inch $\left.^{2}\right)$

$\mathrm{t}=$ time (days)

$\mathrm{CR}=$ Corrosion rate of metal piece

The same procedure was done twice again for another two similar batches of metal coupons in order of after 30 and 45 days from the immersion to determine the corrosion rates of such metal coupons.

As the confirmations of the formations of the corrosion on the metal surfaces decay concentrations of copper and ferrous in to crude oils while the interaction was measured by the atomic absorption spectroscopy (AAS). In the sample preparation $1 \mathrm{ml}$ of each crude oil sample was diluted with 9 $\mathrm{ml}$ of 2-propanol and filtered.
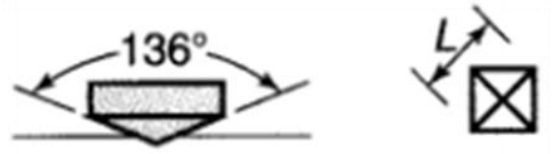

Figure 4. Indenter of the Vicker's hardness tester

Also the variations of the initial hardness due the formations of the corrosion were tested by the by the Vicker's hardness 
tester. As the essential measurements of the experiment. The theory behind the Vicker's hardness tester has been discussed in the section of theories and methodologies [1-5].

The working principles of the Vicker's hardness tester have been shown in Figure 4.

$$
\mathrm{HV}=1.854 * \mathrm{P}^{2} / \mathrm{L}^{2}
$$

where;

$\mathrm{P}=$ Applied Load on the surface of metal

$\mathrm{L}=$ Diagonal length of square

$\mathrm{HV}=$ Hardness

In the digital Vicker's hardness tester the calculated value for the hard ness is displayed. As the accuracy step the hardness of at least three positions on each metal coupon were measured for one measurement.

\section{RESULTS, ANALYSIS AND DISCUSSION}

The obtained results for the analysis of X-ray fluorescence of the chemical compositions of selected metals have been given in the Table 2 .

Table 2. Chemical compositions of metals

\begin{tabular}{c|c|c|c|c}
\hline Metal & $\begin{array}{c}\mathbf{F e} \\
(\mathbf{\%})\end{array}$ & $\begin{array}{c}\mathbf{N i} \\
(\mathbf{\%})\end{array}$ & $\begin{array}{c}\mathbf{C r} \\
(\boldsymbol{\%})\end{array}$ & $\begin{array}{c}\mathbf{C u} \\
(\mathbf{\%})\end{array}$ \\
\hline (1) Carbon Steel (High) & 98.60 & 0.17 & 0.14 & 0.37 \\
\hline $\begin{array}{c}\text { (2) Carbon Steel } \\
\text { (Medium) }\end{array}$ & 99.36 & - & - & - \\
\hline $\begin{array}{c}\text { (3) Carbon Steel } \\
\text { (Mild Steel) }\end{array}$ & 99.46 & - & $<0.07$ & - \\
\hline $\begin{array}{c}\text { (4) 410-MN: } 1.8 \\
\text { 420-MN: } 2.8 \\
\text { (Stainless Steel) }\end{array}$ & 88.25 & 0.18 & 10.92 & 0.10 \\
\hline $\begin{array}{c}\text { (5) 410-MN: 1.7 } \\
\text { 420-MN: 1.7 } \\
\text { (Stainless Steel) }\end{array}$ & 87.44 & - & 11.99 & - \\
\hline $\begin{array}{c}\text { (6) 321-MN: 1.4 } \\
\text { 304-MN: 1.9 } \\
\text { (Stainless Steel) }\end{array}$ & 72.47 & 8.65 & 17.14 & - \\
\hline (7) Monel 400 & 1.40 & 64.36 & $<0.04$ & 33.29 \\
\hline
\end{tabular}

The observed results showed the higher ferrous concentrations in carbon steels, moderate ferrous concentrations in stainless and trace ferrous concentrations in Monel. As the special observations there were obtained some relatively higher compositions of trace metals in stainless steels such as nickel and chromium. The stainless is a modified form of metals by doping some amounts of d-block elements because of the enhancements of the strength and the corrosive stability of such metals $[1,3,5,6]$.

According to the analysis of the corrosive compounds in both crude oils the observed results have been interpreted in the Table 3 .

In the analysis of the magnitudes of the values of the corrosive properties it can be concluded that the Das Blend crude oils was composed relatively higher amount of organic acids, elemental sulfur, Mercaptans and lower amount of salts than Murban crude oil. Since it is impossible to concluded the corrosive strength of such crude oils only considering the magnitudes of the corrosive compounds and also mandatory to consider the required conditions as well.

When considering the average corrosion rates of metal coupons mainly identified some relatively higher corrosion rates from carbon steels, intermediate corrosion rates from Monel and mild steels and lower corrosion rates from stainless steels as usual. Among the corrosion rates of stainless steels the lowest corrosion rates were observed from 321-MN:1.4 304-MN: 1.9 (Stainless Steel) with respect to both Murban and Das Blend crude oils.

According to the microscopic analysis of the corroded metal surfaces some specific corrosive compounds were identified upon their visible appearances. Some of the identified corrosion compounds have been shown in the Figure 5.

Table 3. Corrosive properties of crude oils

\begin{tabular}{ccl}
\hline Property & Murban & Das Blend \\
\hline Sulfur content $(\mathrm{Wt} . \%)$ & 0.758 & 1.135 \\
Salt content $(\mathrm{ptb})$ & 4.4 & 3.6 \\
Acidity (mg KOH/g) & 0.01 & 0.02 \\
Mercaptans content & 25 & 56 \\
(ppm) & & \\
\hline
\end{tabular}

Table 4. Corrosion rates of metals in Murban

\begin{tabular}{|c|c|c|c|c|}
\hline Metal & $\begin{array}{c}\text { Corrosion } \\
\text { Rate after } \\
15 \text { Days } \\
\left(\mathbf{c m}^{3} \text { inch }\right. \\
\left.\mathbf{1}^{-} \mathbf{d a y}^{-1}\right)\end{array}$ & $\begin{array}{c}\text { Corrosion } \\
\text { Rate after } \\
30 \text { Days } \\
\left(\mathbf{c m}^{3} \text { inch- }\right. \\
\left.{ }^{1} \text { day }^{-1}\right)\end{array}$ & $\begin{array}{c}\text { Corrosion } \\
\text { Rate after } \\
45 \text { Days } \\
\left(\mathbf{c m}^{3} \text { inch }\right. \\
\left.{ }^{1} \text { day }^{-1}\right) \\
\end{array}$ & $\begin{array}{c}\text { Average } \\
\text { Corrosion } \\
\text { Rate } \\
\left(\mathbf{c m}^{3} \text { inch }^{-}\right. \\
\left.{ }^{1} \text { day }^{-1}\right)\end{array}$ \\
\hline $\begin{array}{c}(1) \\
\text { Carbon } \\
\text { Steel } \\
\text { (High) } \\
\end{array}$ & 0.811971 & 0.466425 & 0.068794 & 0.4490632 \\
\hline $\begin{array}{c}(2) \\
\text { Carbon } \\
\text { Steel } \\
\text { (Medium) } \\
\end{array}$ & 0.817791 & 0.180339 & 0.073358 & 0.3571623 \\
\hline $\begin{array}{c}(3) \\
\text { Carbon } \\
\text { Steel } \\
\text { (Mild } \\
\text { Steel) } \\
\end{array}$ & 0.10973 & 0.048244 & 0.038592 & 0.0655217 \\
\hline $\begin{array}{c}\text { (4) 410- } \\
\text { MN: } \\
1.8420- \\
\text { MN: } 2.8 \\
\text { (Stainless } \\
\text { Steel) }\end{array}$ & 0.041784 & 0.016075 & 0.011801 & 0.02322 \\
\hline $\begin{array}{c}\text { (5) 410- } \\
\text { MN: } 1.7 \\
420-\mathrm{MN} \text { : } \\
1.7 \\
\text { (Stainless } \\
\text { Steel) }\end{array}$ & 0.11626 & 0.011968 & 0.007574 & 0.0452676 \\
\hline $\begin{array}{c}\text { (6) } 321- \\
\text { N:1.4 } \\
\text { 304-MN: } \\
1.9 \\
\text { (Stainless } \\
\text { Steel) } \\
\end{array}$ & 0.016612 & 0.007453 & 0.005599 & 0.009888 \\
\hline $\begin{array}{l}\text { (7) Monel } \\
400\end{array}$ & 0.356263 & 0.034877 & 0.026729 & 0.13929 \\
\hline
\end{tabular}


Table 5. Corrosion rates of metals in Das Blend

\begin{tabular}{|c|c|c|c|c|}
\hline Metal & $\begin{array}{c}\text { Corrosion Rate } \\
\text { after } 15 \text { Days } \\
\left(\mathrm{cm}^{3} \text { inch }^{-1} \text { day }^{-1}\right) \\
\end{array}$ & $\begin{array}{c}\text { Corrosion Rate } \\
\text { after } 30 \text { Days } \\
\left(\mathrm{cm}^{3} \text { inch }^{-1} \text { day }^{-1}\right) \\
\end{array}$ & $\begin{array}{c}\text { Corrosion Rate } \\
\text { after } 45 \text { Days } \\
\left(\mathrm{cm}^{3} \text { inch }^{-1} \text { day }^{-1}\right) \\
\end{array}$ & $\begin{array}{c}\text { Average Corrosion } \\
\text { Rate } \\
\left(\mathrm{cm}^{3} \text { inch }^{-1} \text { day }^{-1}\right) \\
\end{array}$ \\
\hline (1) Carbon Steel (High) & 0.350249 & 0.224901 & 0.024738 & 0.1999627 \\
\hline (2) Carbon Steel (Medium) & 0.481055 & 0.140654 & 0.05911 & 0.2269396 \\
\hline (3) Carbon Steel (Mild Steel) & 0.162883 & 0.141093 & 0.100635 & 0.1348702 \\
\hline $\begin{array}{l}\text { (4) 410-MN: } 1.8 \text { 420-MN: } 2.8 \\
\text { (Stainless Steel) }\end{array}$ & 0.044146 & 0.034035 & 0.006149 & 0.0281102 \\
\hline $\begin{array}{l}\text { (5) 410-MN: } 1.7 \text { 420-MN: } 1.7 \\
\text { (Stainless Steel) }\end{array}$ & 0.053701 & 0.034841 & 0.016363 & 0.0349681 \\
\hline $\begin{array}{l}\text { (6) 321-MN:1.4 304-MN:1.9 } \\
\text { (Stainless Steel) }\end{array}$ & 0.022894 & 0.006503 & 0.002825 & 0.0107404 \\
\hline (7) Monel 400 & 0.061554 & 0.037655 & 0.016067 & 0.0384254 \\
\hline
\end{tabular}
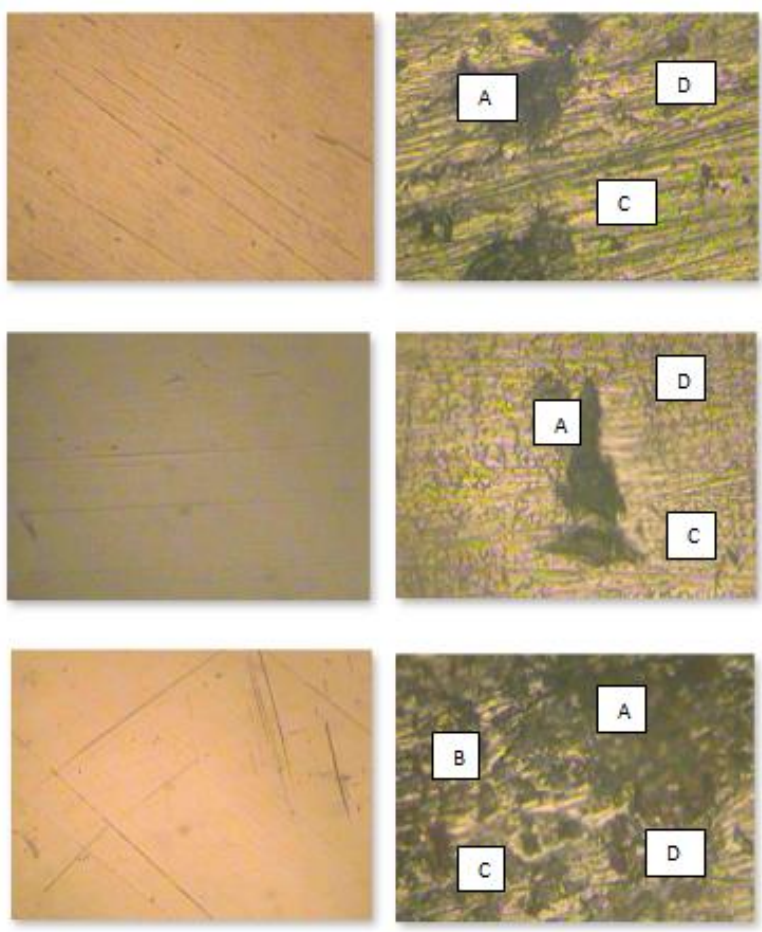

Figure 5. Corroded metal surfaces of metals

The identified corrosion compounds and their visible appearances of such compounds have been discussed in the Table $6[1,3-5]$.
A- Ferrous Sulfide
B- Ferrous Oxide
C- Corrosion Cracks
D- Pits and trace compounds

Table 6. Physical appearances of corrosion compounds

\begin{tabular}{ccc}
\hline Compound & Appearances & Observations \\
\hline $\mathrm{FeS}$ & $\begin{array}{c}\text { Black, brownish } \\
\text { black, property of } \\
\text { powder, pitting, } \\
\text { cracks } \\
\mathrm{Fe}_{2} \mathrm{O}_{3}\end{array}$ & $\begin{array}{c}\text { Observed most of } \\
\text { fusty color } \\
\text { metal piece. }\end{array}$ \\
$\mathrm{CuS}$ & $\begin{array}{c}\text { Dark indigo/ dark } \\
\text { blue, property of } \\
\text { powder }\end{array}$ & Observed rarely. \\
& Unable to specify. \\
\hline
\end{tabular}

According to the atomic absorption spectroscopic (AAS) analysis the obtained results for the decayed ferrous and copper concentrations into crude oils from the metals have been interpreted in the Table 7 .

Table 7. Decayed metal concentrations into crude oils

\begin{tabular}{|c|c|c|c|}
\hline Metal & $\begin{array}{l}\text { Crude } \\
\text { Oil }\end{array}$ & $\begin{array}{c}\mathrm{Fe} \\
\text { Concentration } \\
/ \mathrm{ppm}\end{array}$ & $\begin{array}{c}\mathrm{Cu} \\
\text { Concentration } \\
/ \mathrm{ppm}\end{array}$ \\
\hline \multirow{2}{*}{$\begin{array}{l}\text { Carbon Steel } \\
\text { (High) }\end{array}$} & Murban & 0.47 & - \\
\hline & $\begin{array}{l}\text { Das } \\
\text { Blend }\end{array}$ & 1.10 & - \\
\hline \multirow[b]{2}{*}{$\begin{array}{l}\text { Carbon Steel } \\
\text { (Medium) }\end{array}$} & Murban & 0.54 & - \\
\hline & $\begin{array}{c}\text { Das } \\
\text { Blend } \\
\end{array}$ & 0.02 & - \\
\hline \multirow[b]{2}{*}{$\begin{array}{l}\text { Carbon Steel } \\
\text { (Mild Steel) }\end{array}$} & Murban & -0.08 & - \\
\hline & $\begin{array}{c}\text { Das } \\
\text { Blend }\end{array}$ & -0.48 & - \\
\hline \multirow{2}{*}{$\begin{array}{c}\text { 410-MN: } 1.8 \\
\text { 420- MN: } 2.8 \\
\text { (Stainless Steel) }\end{array}$} & Murban & -0.65 & - \\
\hline & $\begin{array}{c}\text { Das } \\
\text { Blend } \\
\end{array}$ & -0.78 & - \\
\hline \multirow{2}{*}{$\begin{array}{c}\text { 410-MN: } 1.7 \\
\text { 420-MN: } 1.7 \\
\text { (Stainless Steel) }\end{array}$} & Murban & -0.71 & - \\
\hline & $\begin{array}{c}\text { Das } \\
\text { Blend } \\
\end{array}$ & -0.79 & - \\
\hline \multirow{2}{*}{$\begin{array}{c}\text { 321-MN:1.4 } \\
\text { 304-MN:1.9 } \\
\text { (Stainless Steel) }\end{array}$} & Murban & -0.44 & - \\
\hline & $\begin{array}{c}\text { Das } \\
\text { Blend }\end{array}$ & -0.17 & - \\
\hline \multirow[b]{2}{*}{$\begin{array}{l}\text { Monel } \\
400\end{array}$} & Murban & - & 10.47 \\
\hline & $\begin{array}{c}\text { Das } \\
\text { Blend } \\
\end{array}$ & - & 9.49 \\
\hline
\end{tabular}

The atomic absorption spectroscopic results showed the significant decay of copper from Monel metal, relatively higher decay of ferrous from carbon steels and there were not observed any decay concentrations neither copper nor ferrous from any kind of stainless steel.

The average corrosion rates of metals with respect to both and Murban and Das Blend crude oils are interpreted in the graph of Figure 6.

According to the summary of the corrosion rates of metal coupons that there can be emphasized the relatively lower corrosion rates of stainless steels especially 321-MN:1.4 304MN: 1.9 (Stainless Steel) has shown least corrosion rates in both crude oils. In the analysis with the chemical composition of that metal it was composed $\sim 18 \%$ of chromium and $\sim 8.65 \%$ of nickel. The combination of the $\sim 12 \%$ of chromium with sufficient amount of nickel tend to be formed a self corrosion protection film. Therefore, it can be concluded the performances of such self corrosion protection film is taken place when having at least $12 \%$ chromium with sufficient amount of nickel [1, 3-6]. 


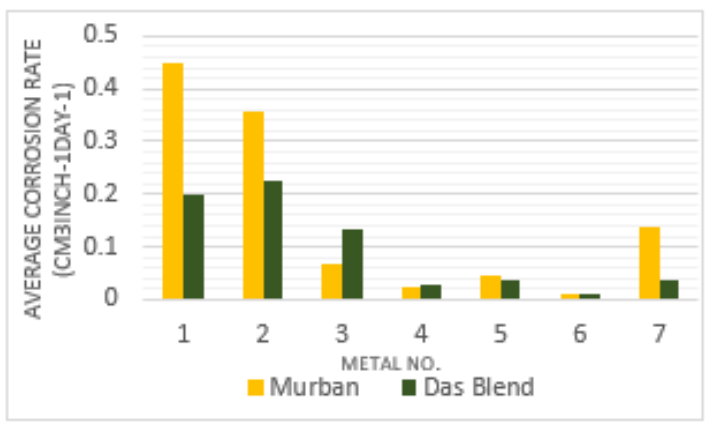

Figure 6. Average corrosion rates of metals

The variations of the corrosion rates of metals with the exposure time in both crude oils have been interpreted in the Figure 7 and Figure 8.

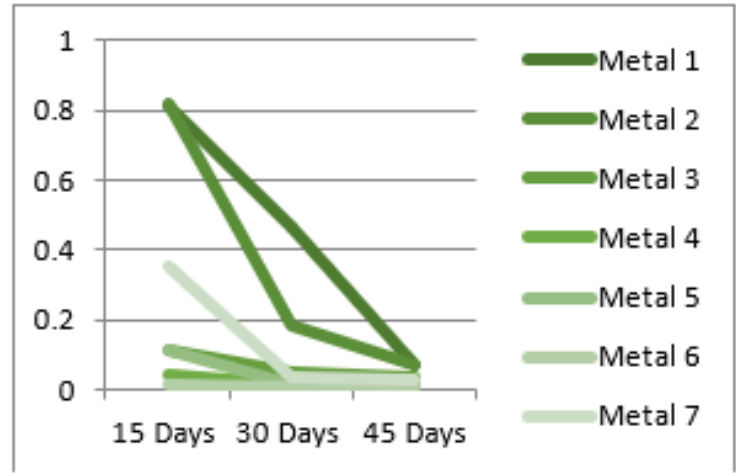

Figure 7. Variations of the corrosion rates of metals in Murban

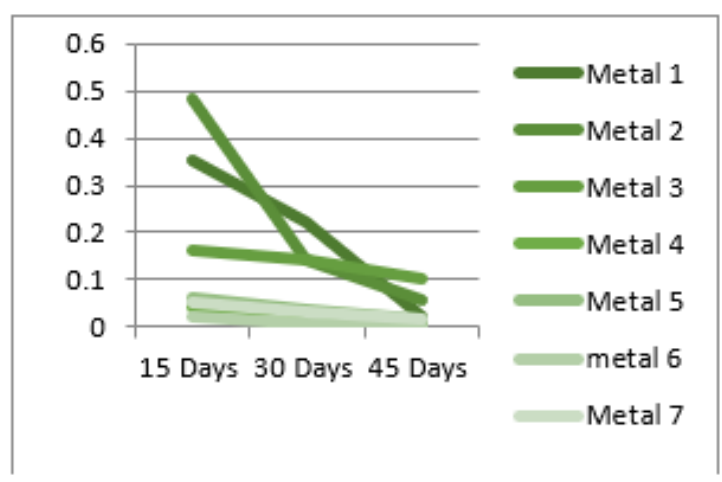

Figure 8. Variations of the corrosion rates of metals in Das Blend

By referring the above distributions that there can be concluded much similar variations of the variation curves of the corrosion rates with the exposure time. These results can be used as the confirmations for the accuracy of the weight loss method for various material that the inversely proportional relationship between the corrosion rate and the exposure time [9, 10].

The corrosive impacts of the various corrosive compounds of crude oils have been discussed in the below.

Organic acids are the frequently found corrosive compounds in crude oils also known as naphthenic acids which are having a chemical formula of $\mathrm{RCOOH}$.

The total amount of organic acids presence in some crude oil is known as the acidity or the total acid number (TAN) of such crude oil and such organic are highly oxidizing agents against the metals. The general chemical reactions between the metals and organic acids have been given in the below [2, 4, 9, $12,15]$.

$$
\begin{aligned}
& \mathrm{Fe}+2 \mathrm{RCOOH} \rightarrow \mathrm{Fe}(\mathrm{COOR})_{2}+\mathrm{H}_{2} \\
& \mathrm{FeS}+2 \mathrm{RCOOH} \rightarrow \mathrm{Fe}(\mathrm{COOR})_{2}+\mathrm{H}_{2} \mathrm{~S} \\
& \mathrm{Fe}(\mathrm{COOR})_{2}+\mathrm{H}_{2} \mathrm{~S} \rightarrow \mathrm{FeS}+2 \mathrm{RCOOH}
\end{aligned}
$$

Salts are the dominant corrosive compounds that found from the crdue oils since the occurrences. Basically three types of salts are presence in crude oils such as $\mathrm{NaCl}, \mathrm{MgCl}_{2}, \mathrm{CaCl}_{2}$ and the summation of such halides in some crude oil is known as the salt content of such crude oil. When heating the crude oils such salts tend to be broken into $\mathrm{HCl}$ although noncorrosive at the higher temperatures. At the lower temperatures such $\mathrm{HCl}$ molecules are reacted with moisture or water presence in crude oils and produced highly corrosive hydrochloric acids. The steps of the corrosion process that related with salts have been given in the below $[2,4,7]$.

$$
\begin{aligned}
& \mathrm{CaCl}_{2}+\mathrm{H}_{2} \mathrm{O} \rightarrow \mathrm{CaO}+2 \mathrm{HCl} \\
& 2 \mathrm{HCl}+\mathrm{Fe} \rightarrow \mathrm{FeCl}_{2}+\mathrm{H}_{2} \\
& \mathrm{H}_{2}+\mathrm{S} \rightarrow \mathrm{H}_{2} \mathrm{~S} \\
& \mathrm{FeCl}_{2}+\mathrm{H}_{2} \mathrm{~S} \rightarrow \mathrm{FeS}+2 \mathrm{HCl}
\end{aligned}
$$

Sulfur compounds are the various forms of corrosion compounds because of the presence of highly reactive functional groups of such sulfur compounds since the occurrences of such crude oils because of the abundancy of sulfur in the interior parts of the earth. Among sulfur compounds most of them have been classified into corrosive compounds such as elemental sulfur, hydrogen sulfides, Mercaptens, sulfoxides and thiophenes. According to the type of functional group and the reactivity of such functional group the chemical reactions process may be happened under various conditions mainly at different temperatures. According to the scope of current research that there were considered two corrosion processes as explained in the below [2, 4, 13, 14].

Localized corrosion is a corrosion process that related with the elemental sulfur basically tend be happened at $80{ }^{\circ} \mathrm{C}$ properly.

Sufidation is a corrosion process that related with the Mercaptans which is having some highly reactive functional group of "RSH". This chemical reaction also happened in the temperature range of $230-460{ }^{\circ} \mathrm{C}$ properly. The basic chemical reactions for the above corrosion process have been given in the below $[13,14]$.

$$
\begin{gathered}
\mathrm{S} 8(\mathrm{~s})+8 \mathrm{H}_{2} \mathrm{O}(\mathrm{l}) \rightarrow 6 \mathrm{H}_{2} \mathrm{~S}(\mathrm{aq})+2 \mathrm{H}_{2} \mathrm{SO}_{4}(\mathrm{aq}) \\
8 \mathrm{Fe}+\mathrm{S} 8 \rightarrow 8 \mathrm{FeS}
\end{gathered}
$$

According to the overall analysis of the impact of the corrosive strength of both crude oils with the obtained results for the corrosion rates of metals four types of metals were shown their higher corrosion rates in Murban crude oils since other three types of metals were shown their higher corrosion rates in Das Blend. Therefore, it is possible to conclude the corrosion impact of salts is much higher than the impact of 
other corrosion compounds at the lower temperatures.

Also it is possible to recommend some further analysis of the impact of various corrosion compounds such as hydrogen sulfides and other sulfur compounds especially at the various temperatures for the better results.

The concluded results of the analysis of the decayed ferrous and copper concentrations into crude oils from metals have been interpreted in the Figure 9 and Figure 10.

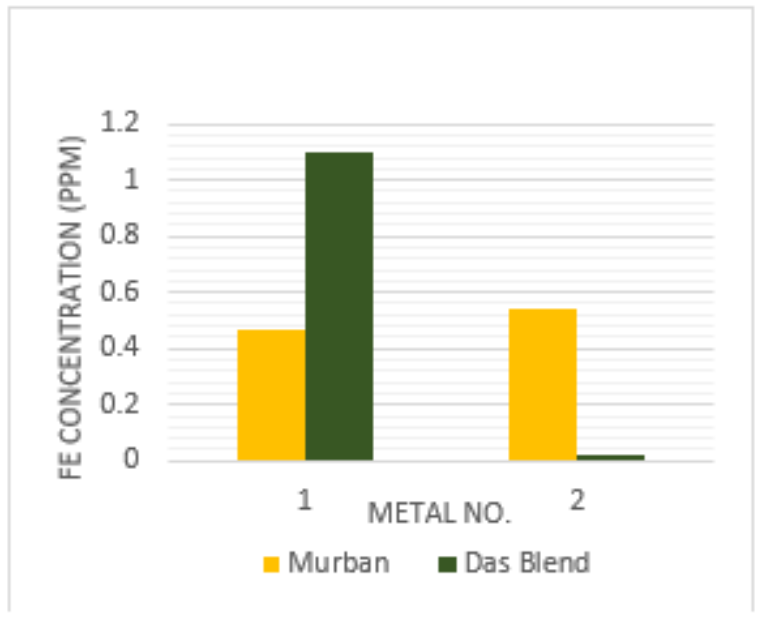

Figure 9. Decayed ferrous concentrations into crude oils

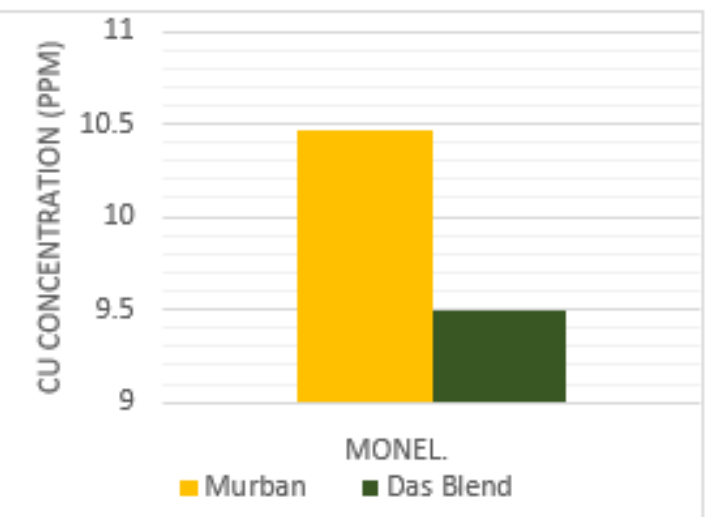

Figure 10. Decayed copper concentrations into crude oils

The both graphs showed the relatively higher decay of ferrous from carbon steels and significant decay of copper from Monel were observed. As a special observation that there were observed null decay concentrations from stainless steels also found least corrosion rates from stainless steels. While the corrosion process some of corrosion compounds tend to be removed from the netal surfaces because of the repulsive and attractive forces between the successive electrons and protons of existing compounds. Therefore, the decay of the metallic elements into crude oils is explained under the theory of electron repulsive and attractive and also the decay of metals into crude oils is happened due to the formations of the corrosion [1, 3-6].

The obtained results for the variations of the initial hardness of metal coupons were interpreted in the Figure 11 and Figure 12.

Those graphs showed the slight reductions of the initial hardness of most of metals after the corrosion in approximately similar amounts. The reductions of the initial hardness sis possible to explained under the same theory of electron repulsive and attractive. After formations of the corrosion compounds on the metallic surface such compounds tend to be removed either partially or completely from the metal surfaces due to the attractive and repulsive forces between the successive electrons and protons of such compounds while creating an unstable condition of the metal surfaces due to the heterogeneous moment [1, 3-5]. The reduction of the initial hardness also possible to happen under such situation. Furthermore these results showed the formations of the corrosion on the metal surfaces in most of occasions.

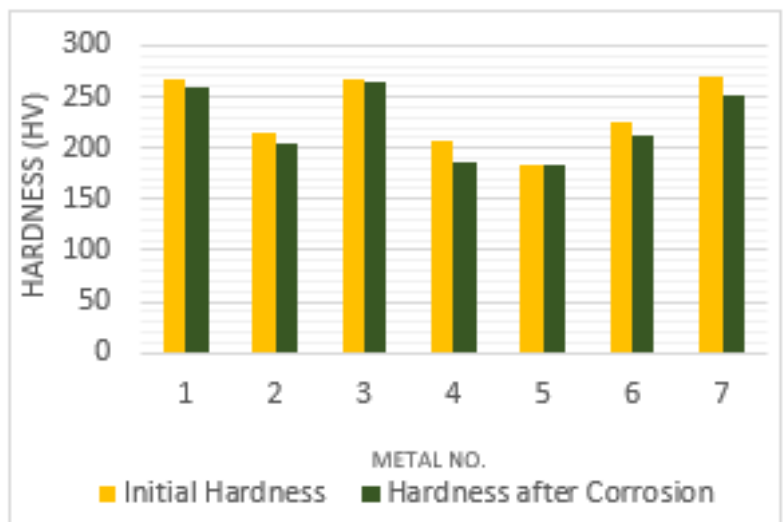

Figure 11. Variations of the initial hardness of metals in Murban

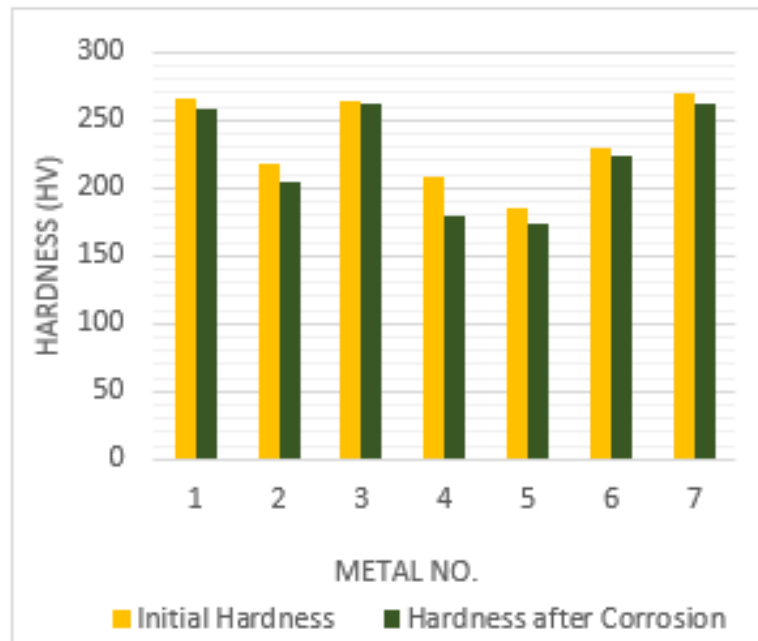

Figure 12. Variations of the initial hardness of metals in Das Blend

\section{CONCLUSION}

In this research the major outcomes and findings can be emphasized as the a few of investigations. Basically the investigations of the less corrosive tendency of stainless steels with the chemical compositions of at least $12 \%$ of chromium and nickel in the recommended percentages, significant contributions of the salts on the metallic corrosion when comparing with the corrosive impacts of organic acids and sulfur compounds at the room temperatures, formations of $\mathrm{FeS}$ frequently, formations of $\mathrm{Fe}_{2} \mathrm{O}_{3}$, irregular corrosion cracks and asymmetric pits on the corroded metal surfaces, decays of copper and ferrous from carbon steels and Monel while non decay of any metallic element from stainless steels and slight reductions of the initial hardness of most of metal coupons due 
to the formations of the corrosion. As the alterations of the existion research it is possible to continue up to further levels through the advanced and useful analysis as recommended in the below.

$\checkmark$ Compositional analysis of the corrosion compounds that formed on the metal surfaces by an advanced analytical method such as the X-ray diffraction (XRD).

$\checkmark$ Analysis of the more decayed metallic elements from the metals while the immersion in petroleum oils other than the ferrous and copper by the same methodology.

$\checkmark$ Entending of the research with the determinations of the corrosion rates of metals by the advanced electrical method simultaneously with the mechanical method to enhance the accuracy.

$\checkmark$ Analysis of more corrosive compounds that presence in more different petroleum oil and also the analysis of the required environmental conditions for the relevant chemical processes for the optimal progress.

\section{ACKNOWLEDGEMENT}

The research was basically accommodated by Ceylon Petroleum Cooperation, University of Mortauwa and Uva Wellassa University.

\section{REFERENCES}

[1] Khana, O.P. (2009). Materials Science and Metallurgy. New Delhi: Dhanpet Rai and Sons publication.

[2] Fahim, M.A., Alsahhaf, T.A., Elkilani, A. (2010). Fundamentals of Petroleum Refining. Elsevier. https://doi.org/10.1016/c2009-0-16348-1

[3] Calister, W.D. (2003). An Introduction of Materials Science and Engineering. New York: John Wiley and Sons.

[4] Davis, M.E., Davis, R.J. (2003). Fundamentals of Chemical Reaction Engineering. New York: McGrawHill.
[5] Singh, R. (2006). Introduction to Basic Manufacturing Process and Engineering Workshop. New Delhi: New Age International Publication.

[6] Bolton, W. (1993). Engineering Materials Technology. Elsevier. https://doi.org/10.1016/c2013-0-04622-1

[7] Ajimotokan, H.A., Badmos, A.Y., Emmanuel, E.O. (2009). Corrosion in petroleum pipelines. New York Science Journal, 2(5): 36-40.

[8] Speight, J.G. (1999). The Chemistry and Technology of Petroleum. Boca Raton. https://doi.org/10.1201/9780824742119

[9] Afaf, G.A. (2015). Corrosion treatment of high TAN crude. American Scientific Research Journal for Engineering, Technology, and Sciences (ASRJETS), 11(1): 1-7.

[10] Okpokwasili, G.C., Oparaodu, K.O. (2014). Comparison of percentage weight loss and corrosion rate trends in different metal coupons from two soil environments. International Journal of Environmental Bioremediation \& Biodegradation, 2(5): 243-249. https://doi.org/10.12691/ijebb-2-5-5

[11] Usman, A.D., Okoro, L.N. (2015). Mild steel corrosion in different oil types. International Journal of Scientific Research and Innovative Technology, 2(2): 9-13.

[12] Ahmed, I.M., Elnour, M.M., Ibrahim, M.T. (2014). Study the effects of naphthenic acid in crude oil equipment corrosion. Journal of Applied and Industrial Sciences, 2(6): 255-260.

[13] Rickard, D., Luther, G.W. (2007). Chemistry of iron sulfides. Chemical Reviews, 107(2): 514-562. https://doi.org/10.1021/cr0503658

[14] Fang, H., Nesic, S., Young, D. (2008). Corrosion of mild steel in the presence of elemental sulfur. International Corrosion Conference and Expo.

[15] Bota, G.M., Nesic, S., Qu, D., Wolf, H.A. (2010). Naphthenic acid corrosion of mild steel in the presence of sulfide scales formed in crude oil fractions at high temperature. International Corrosion Conference and Expo. 